\title{
Linking Local Perceptions to the Biophysical and Amenity Contexts of Forest Disturbance in Colorado
}

\author{
Courtney Flint · Hua Qin · Joanna P. Ganning
}

Received: 12 August 2009/Accepted: 10 December 2011/Published online: 22 January 2012

(C) Springer Science+Business Media, LLC 2012

\begin{abstract}
Disturbances by insects have considerable effect on the heterogeneity of forested landscapes in North America. Responding to calls for bringing human dimensions of landscape disturbance and heterogeneity into ecological assessments and management strategies, this paper explores linkages between biophysical, socioeconomic, and perceptual aspects of a mountain pine beetle (MPB) (Dendroctonus ponderosae) outbreak in north central Colorado. Findings are presented from surveys conducted with residents of nine Colorado communities and variations in local perceptions of MPB risks and forest management attitudes are compared to indices of tree mortality and amenity characteristics. Findings suggest respondents from lower amenity communities with more recent emphasis on resource extraction and higher tree mortality had significantly higher risk perceptions of some MPB impacts, lower trust in federal forest management, and higher faith in forest industry and specific industry options than those from higher amenity communities with less tree mortality. While not implying these contextual influences fully explain such perceptual dimensions, this paper explores possible implications of heterogeneity
\end{abstract}

C. Flint $(\bowtie)$

Department of Natural Resources and Environmental Sciences, University of Illinois, Urbana-Champaign, S510 Turner Hall, 1102 S. Goodwin Avenue, Urbana, IL 61801-4778, USA e-mail: cflint@uiuc.edu

H. Qin

Climate Science and Applications Program, National Center for Atmospheric Research, P.O. Box 3000, Boulder,

CO 80307, USA

J. P. Ganning

Public Policy Planning Department, Saint Louis University, St. Louis, MO, USA across human landscapes for improving the saliency and efficiency of regional forest management and planning.

Keywords Amenity context - Forest disturbance . Landscape heterogeneity - Mountain pine beetles . Resource management attitudes $\cdot$ Risk perceptions

\section{Introduction}

Forest disturbances by insects increasingly make headline news and attract the attention of citizens, scientists and resource managers alike. A perfect storm of forest stand conditions and changing climate parameters has led to unusually large swaths of tree mortality by insects across forest landscapes in North America. Climate change at local, regional, and global scales may increasingly influence the "occurrence, timing, frequency, duration, extent, and intensity of disturbances" (Dale and others 2001, p. 723), thus altering forest landscapes and ecosystems. However, discussions of coping strategies for managing disturbance effects on forests rarely mention interactions with human communities or socioeconomic dimensions of forest management.

The study of human dimensions of landscape disturbance by forest insects is increasingly reflected in the natural resource sociology and environmental management literature (Chang and others 2009; Flint 2006, 2007; Flint and Haynes 2006; Flint and Luloff 2007; Flint and others 2009; McFarlane and Wilson 2008; Parkins and MacKendrick 2007). Resource managers find themselves adapting to local human contexts in addition to changing biophysical parameters of forest disturbances (Flint and others 2009). Landscape heterogeneity, or diversification of attributes across a particular area, is a cornerstone principle 
of ecological research on disturbance and ecological change (Pickett and Cadenasso 1995; Turner 1989; Wiens 1995, 2000). However, socioeconomic and perceptual impacts of forest disturbances by insects largely remain in a separate realm of social science, rarely integrated with the study of biophysical or ecological processes. Energizing multi-disciplinary integration around ecosystem disturbance experience promotes robust ecosystem management (Pickett and others 1997).

This paper explores connections among biophysical, socioeconomic, and perceptual dimensions of forest disturbance by insects in north central Colorado where mountain pine beetles (MPB) (Dendroctonus ponerosae) have killed over 1 million acres of lodgepole (Pinus contorta) and ponderosa pine (Pinus ponderosa) forests. Communities situated within this changing forest are characterized by their natural and recreational amenities with varying socioeconomic ramifications. This context and local experience with tree mortality varies across our nine study communities. Findings from surveys with residents provide insights into variations in risk perceptions and local attitudes in response to changing forest conditions. The amenity context and the extent of tree mortality are obviously independent of each other, but together were expected to both shape the context of perceptions of landscape disturbance with important implications for forest management.

\section{Expanding the Scope of Landscape Heterogeneity Inquiry}

Disturbances by insects are likely to influence heterogeneity in forest ecosystems. Landscape mosaics emerging from disturbed ecosystems often reflect extensive variability in ecological characteristics (Pickett and Cadenasso 1995). Connections between insect activity and other disturbances such as fire, introduced species and weather events are common and can change the arrangement of growing space for species and other physical environment parameters (Dale and others 2001; Oliver and Larson 1996; Pickett and White 1985).

Landscape ecology, or the study of relationships between spatial patterns and ecological processes, has established spatial heterogeneity as a cornerstone of investigation (Pickett and Cadenasso 1995; Turner 1989; Wiens 1995, 2000). Yet, landscape ecology has largely separated or simplified human dimensions of landscapes and a number of scholars have lamented the lack of explicit integration of socioeconomic or human dimensions of spatial heterogeneity (Pickett and others 1997; Radeloff and others 2001; Turner 2005). The incongruence of jurisdictional boundaries and temporal and spatial scales of ecological processes present a "daunting challenge to ecosystem management"
(Christensen 1997, p. 171). Understanding the political and social dimensions of landscapes is essential for managing resource objectives. Indeed, "Nature can no longer be conceived of without humans" (Ostfeld and others 1997, p. 8).

Delving further into human dimensions is not common in landscape ecology according to Fry, who wrote, "... very few studies have systematically examined relationships between functions related to ecological sustainability and the human perception of landscape" (2001, p. 159). While some have recognized and called for the inclusion of societal objectives, values, and perceptions (Forman 1999; Ostfeld and others 1997), landscape ecology has largely disregarded 'landscapes of the mind' or the social or mental aspects of landscapes (Haber 2004, p. 104). This omission is problematic since "(e)cology interacts with human values, knowledge, and ethics" (Ostfeld and others 1997 , p. 8). Perceptions are essential elements of understanding landscape change because people "relate themselves to landscapes and are part of it at the same time" (Tress and Tress 2001, p. 148; see also Cronon 1996). Perceptions may lead people to modify their decisions and actions, thus influencing the shape and condition of landscapes (Nassauer 1995; Tress and Tress 2001). Gathering perceptual information requires research methods that engage stakeholders since "The best cultural indicators of landscape ecological quality may not be readily available numbers, like the economic and demographic data we have gathered for decades" (Nassauer 2005, p. 275).

\section{Human and Community Response to Forest Disturbance by Insects}

Research on the human dimensions of forest disturbances by insects has explored economic implications (Abbott 2008; Patriquin and others 2007), tourist or visitor attitudes (McFarlane and Wilson 2008; Müller and Job 2009), landowner actions (Molnar and others 2007), community impacts and vulnerability (Flint 2006; Parkins and MacKendrick 2007), province comparison of public attitudes toward forest pests and control (Chang and others 2009), community attitudes, risk perceptions, and attitudes (Flint and Haynes 2006; Flint and Luloff 2007; McFarlane and others 2006), and policy and management implications (Chang and others 2009; Flint and others 2009; Nelson 2007). These studies collectively suggest forest disturbances have a wide array of socioeconomic impacts and that the perceptions and experiences of many stakeholders likewise shape management options and strategies. Given the connectedness between forest insect activity and other disturbance dynamics such as fire and large scale timber management, landscape heterogeneity is shaped by the 
interaction of biophysical processes, socioeconomic conditions and structures, management frameworks, and the attitudes and actions of local and regional stakeholders.

To our knowledge, few studies to date have integrated the biophysical parameters of forest disturbance by insects with indicators of community socioeconomic structure and attitudes and risk perceptions of local residents. One key exception is the work of Parkins and MacKendrick (2007) which describes community vulnerability assessments related to the MPB outbreak in British Columbia. By mixing methods, indicators, and dimensions of the forest disturbance experience, Parkins and MacKendrick (2007) assessed risks and potential for adaptive strategies across a number of communities. They found a disconnection between measured and perceived tree mortality and impacts across their four study communities with an overall heightened perception of impact. In their study, risk perceptions were analyzed with respect to trust and satisfaction with various management institutions resulting in similar political capacity scores across the communities. Challenges associated with constructing multi-faceted indices of vulnerability were highlighted, particularly data integration issues and assessing the role of media discourse on local perspectives.

Community variation in response to a spruce bark beetle outbreak (SBB) (Dendroctonus rufipennis) was also assessed on the Kenai Peninsula in Alaska (Brennan and others 2008; Flint and Haynes 2006; Flint and Luloff 2007). The Kenai Peninsula SBB investigation suggested that communities differed in terms of the local culture, risk perceptions and resource management attitudes among their residents. In assessing factors influencing community activeness regarding the spruce bark beetle outbreak, Flint and Luloff (2007) found biophysical vulnerability, measured by the degree of forest mortality and the number of fires in the surrounding area, to significantly influence community activeness by residents, but they focused primarily on aggregate data in their analysis and did not explore the influence of biophysical or structural conditions on variables such as risk perception or attitudes regarding forest management within or across communities.

In this paper, we build on the studies described above in Canada and Alaska. Multivariate analysis of factors influencing action in response to MPBs in north central Colorado is published elsewhere (Qin and Flint 2010). Here, we integrate indicators of tree mortality and amenity context with information gathered on attitudes, risk and impact perceptions from nine Colorado communities affected by MPBs to assess landscape patterns and the degree to which the backdrop of structural indicators correlates at the community level with individual perceptions. The following research questions guided the project and structure our presentation of results:
- What is the relationship between MPB tree mortality and community amenity status?

- How do local perceptions of MPB tree mortality correspond to measures of tree mortality from aerial surveys?

- Do perceived MPB impacts, risk perceptions, and forest management attitudes vary by community and how do they correspond to tree mortality data and/or amenity index values and community clusters?

- What are the management implications of these findings?

\section{Study Area}

Forests in north central Colorado are experiencing a largescale disturbance by MPBs. This extensive MPB outbreak has killed many lodgepole pine (Pinus contorta) and ponderosa pine (Pinus ponderosa) throughout 1.9 million acres $(607,028 \mathrm{ha})$ in the area since 1996 (Leatherman 2008). Although MPB is endemic to Colorado forests, this outbreak is unprecedented in its spatial extent and tree mortality; the forests of Eagle, Grand, Jackson, Routt, and Summit counties are heavily impacted (Hackett 2007).

Nine communities from these five counties were selected for this study: Breckenridge, Dillon, Frisco, Granby, Kremmling, Silverthorne, Steamboat Springs, Vail, and Walden (see Fig. 1). US Census data for the five counties and discussions with representatives from regional USDA Forest Service representatives helped to guide site selection. The nine study communities were chosen to broadly represent the array of local experiences with the MPB outbreak and socioeconomic conditions in the study area. The study area typifies the common western US checkerboard pattern of public and private lands (Bartuska 1999) and includes luxury resort towns (such as Breckenridge and Vail) and nearby amenity-oriented towns of Dillon, Frisco, and Silverthorne. Steamboat Springs is a larger, more diverse city hosting a destination ski resort. The three remaining communities (Granby, Kremmling, and Walden) are also experiencing amenity development, but have more recent experience with resource extraction employment, particularly in ranching and logging. Table 1 shows employment figures for resource extraction and arts and entertainment sectors, showing Granby, Kremmling and Walden to have higher employment in resource extraction in 2000 than the other communities and less employment in entertainment and recreation oriented industries. Breckenridge, Dillon, Frisco, Silverthorne, Steamboat Springs, and Vail are surrounded by or situated close to forested mountains. In contrast, Granby, Kremmling and Walden 


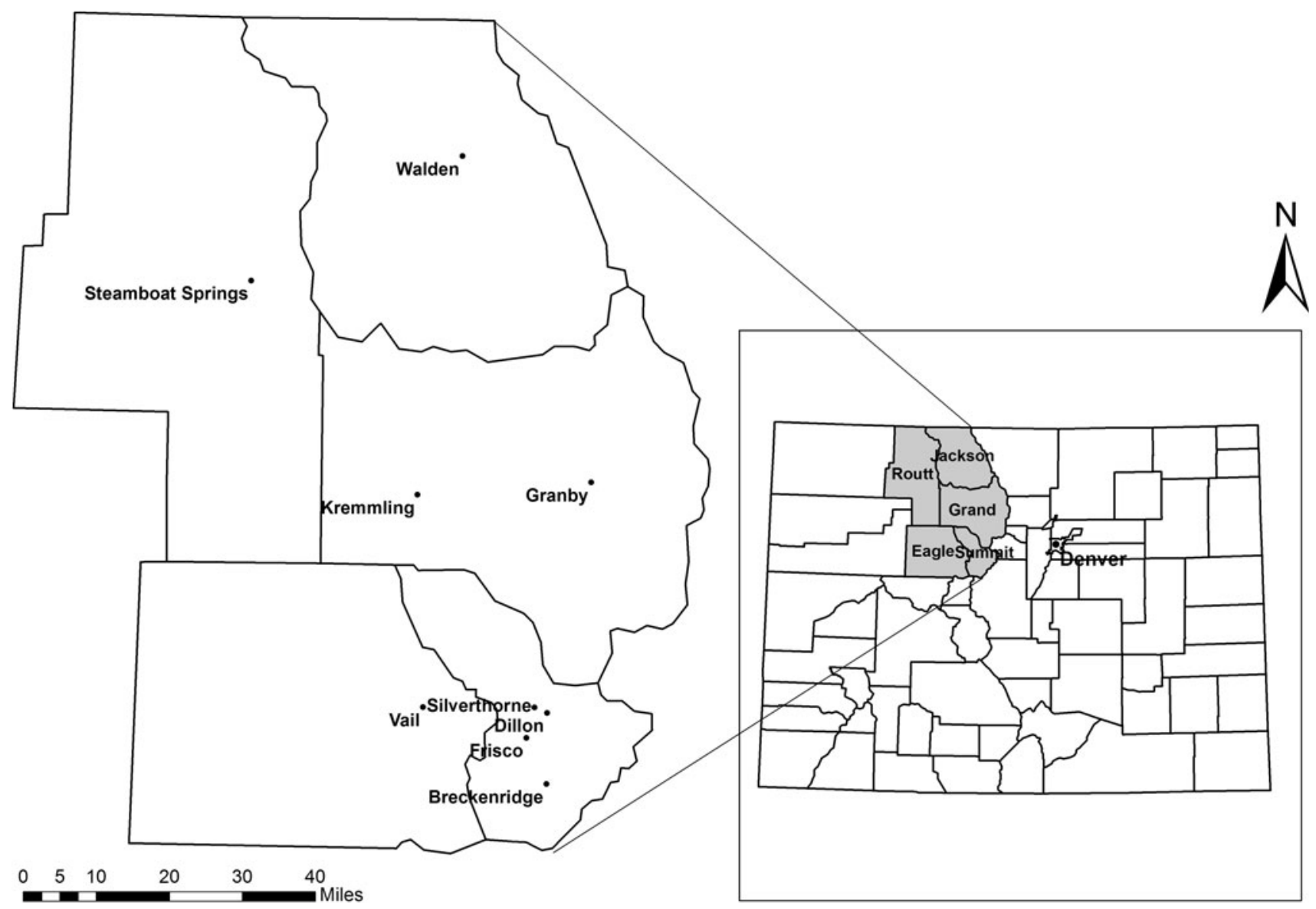

Fig. 1 Map of north central Colorado and study communities. Reprinted with kind permission from Springer Science+Business Media: Qin and Flint (2010, Fig. 2)

Table 1 Employment in two sectors for study communities in 2000 and current or previous employment in agriculture or forestry by survey respondents

\begin{tabular}{llll}
\hline $\begin{array}{l}\text { Study } \\
\text { community }\end{array}$ & $\begin{array}{l}\text { Employment in } \\
\text { Ag, forestry, fishing, } \\
\text { hunting \& mining } \\
\text { in } 2000(\%)^{\mathrm{a}}\end{array}$ & $\begin{array}{l}\text { 2000 Employment in arts, } \\
\text { entertainment, recreation, } \\
\text { accommodation and food } \\
\text { services }(\%)^{\mathrm{a}}\end{array}$ & $\begin{array}{l}\text { Current or previous } \\
\text { employment in agriculture } \\
\text { or forestry among survey } \\
\text { respondents in 2007 }\end{array}$ \\
\hline Granby & 3.7 & 16.6 & 36.4 \\
Kremmling & 9.7 & 8.9 & 55.2 \\
Walden & 10.7 & 3.3 & 69.5 \\
Silverthorne & 2.3 & 22.3 & 18.4 \\
Vail & 0.2 & 37.4 & 22.0 \\
Frisco & 0.0 & 31.7 & 21.8 \\
Dillon & 0.8 & 25.7 & 22.0 \\
Breckenridge & 0.3 & 44.5 & 17.1 \\
Steamboat Springs & 3.2 & 20.7 & 26.1 \\
\hline
\end{tabular}

${ }^{\text {a }}$ US Bureau of the Census (2000)

a US Bureau of the Census
(2000)

are located further from forests in open park-like valleys, but have strong historical ties to timber harvesting and recreational use of forests. Other study community characteristics are captured in the amenity index discussed below.

\section{Methods}

Two modes of data collection and analysis were conducted. Secondary socioeconomic, biophysical, and other available data were compiled to provide information on the structural 
and environmental context for the study, particularly the extent of forests damaged by insects and amenity context. Survey data provided a means of gauging attitudes across larger population samples from the study communities.

\section{Secondary Data Analysis}

Information on the percentage of tree mortality around each community highlights the diffusion and impact of the MPB disturbance. Forest mortality data from aerial insect surveys were obtained from the Rocky Mountain Region of the U.S. Forest Service in 2007. Spatial data on forested areas in and around north central Colorado were obtained from the National Land Cover Database (NLCD) 2001 developed by a consortium of multiple federal agencies called the MultiResolution Land Characteristics (MRLC) Consortium. Based on these data, a biophysical vulnerability variable (percentage of damaged forests) was created indicating the condition of forest cover at different levels of analysis: county, county subdivision, and polygons of different radii (ten, fifteen, and twenty miles) around the census designated place boundaries for each study community. The percentage of damaged trees within fifteen miles of each community was chosen as the most meaningful biophysical context given the variations in distance to forested land around each community. It should be noted that there are inherent weaknesses in using the aerial detection survey data due to discrepancies in tree mortality interpretation among different surveyors flying different areas (McConnell 1995). However, for landscape scale purposes, and for comparison with land-level viewer perceptions, aerial detection survey data are more suitable than extrapolations from ground count data obtained at a micro-scale.

As all nine study communities are focused to some extent on natural resource-based amenities, an amenity index (Ganning and Flint 2010) was used to quantitatively measure natural resource-based amenities and their related socioeconomic characteristics for each community. The amenity index score is a composite of scores from two subindices, the first reflecting the natural amenities themselves, and the second measuring socioeconomic indicators of amenities. This combination mirrors recent literature on amenity communities (Winkler and others 2007) and acknowledges the relationship between natural amenities and growth (McGranahan 1999; Chi and Marcouiller 2010). Triangulating these two dimensions gives a fuller description of the amenity community context which is particularly relevant in the "New West" where demographic and economic shifts are changing the orientation of rural communities and regions (Riebsame and others 1997).

The natural amenity sub-index was developed by measuring forest land cover (from NLCD) within a ten-mile radius, U.S. Forest Service land within a ten-mile radius, and water within a one-mile radius of each community, and by counting the natural resource-based recreation sites (ski slopes, golf courses, fishing access, bike paths, trail heads, boat launches, picnic areas, and camp sites) within ten miles of each community. Information on the location of recreation sites was gathered from U.S. Forest Service maps and from the Colorado Tourism Office website. The variables in this sub-index were standardized and factor analyzed. The loading score on the first component was scaled and used to weight each variable in the sub-index such that the sum of the loadings sums to one for each community, consistent with the method used by Davidson and Shah (1997).

The second sub-index measured socioeconomic indicators of amenities. Using the same method described above, this sub-index combined the following variables (from the U.S. Census Bureau, 1990 and 2000) into one sub-index score: employment diversity (using a Shannon-Weaver score); median household income; percent of housing that is seasonal; population growth from 1990 to 2000; percent of the population that in-migrated from another state between 1995 and 2000; percent of the population that in-migrated from another county between 1995 and 2000; percent with at least a bachelors degree; percent of housing built between 1995 and 2000; percent of owner-occupied houses valued at over $\$ 500,000$; median rent; median value of owner-occupied housing; and share of employment in arts, entertainment, recreation, accommodation and food services.

The two sub-indices were averaged together to create a total amenity index score for each community. This method produced an index robust to slight changes in its constituent variables providing meaningful, interpretable rankings of communities based on actual amenities and their related socioeconomic indicators. This indexing method relying on factor analysis is best used for data that is highly correlated, as is the case with the variables used in this study. In the factor analysis for both sub-indices, the mean value of variable communalities was over .70 . Variables in the analysis were generally well represented by the first factor of each sub-index. All variable loadings except one were above .60. The percent of variance explained by the first factors of the two sub-indices are 70.3 and 69.2 respectively. The high variable communalities and component loadings suggest the stability of factor patterns and reduce concern about the small sample size (Guadagnoli and Velicer 1988; MacCallum and others 2001). The indexing method is better suited to larger sample sizes and we acknowledge the limitations inherent in creating an index for only nine communities. In this case, we used the resulting index to categorize our study communities. This amenity index technique merits further exploration with larger sample sizes. 
Table 2 Factor analysis for risk perception variables (using principal components extraction and varimax rotation)

\begin{tabular}{lc}
\hline Variables & Factor loadings \\
\hline Forest fire & .638 \\
Falling trees & .673 \\
Decline in wildlife habitat & .723 \\
Impact on livestock grazing & .562 \\
Increased erosion and runoff & .728 \\
Invasive plant species & .645 \\
Loss of forests as an economic resource & .728 \\
Loss of scenic/aesthetic quality & .729 \\
Loss of tourism and recreation opportunities & .731 \\
Loss of community identity tied to the forest & .761 \\
Impact on property values & .722 \\
Eigenvalue & 5.336 \\
Percent of variance explained & $48.5 \%$ \\
Cronbach's alpha for composite index variable & .891 \\
\hline
\end{tabular}

Survey Methodology

A mail survey was developed and administered in the spring of 2007 to randomly selected households in the nine study communities and used in a quantitative analysis of community attitudes about the MPB outbreak. The sampling frame consisted of households from a mailing address database purchased from a direct marketing firm USADATA. To help to ensure inclusion of all eligible households, contacts from USADATA were validated and updated using the most recent local telephone directories. Based on this method, household populations for the nine communities were calculated to include both full and parttime residents as follows: Breckenridge 3,714; Dillon 3,081; Frisco 1,857; Granby 1,361; Kremmling 802; Silverthorne 2,186; Steamboat Springs 7,263; Vail 3,803; and Walden 527. In Walden (of Jackson County), we added households from nearby communities, Rand, Cowdrey, Gould, and Coalmont, because preliminary field work revealed Jackson County residents largely considered themselves to be part of a county-wide community. However, Walden households still accounted for a vast majority (84\%) of respondent households from the broad Jackson County area. We refer to this study site as Walden, but acknowledge that this case presents more of a county-wide perspective.

A preliminary sample size for each community was set based on the need to statistically represent the community household population at a confidence level of $95 \%$ and a confidence interval of $6.5 \%$. These sample sizes were doubled in light of the recent trends of declining survey response rates (Connelly and others 2003; Luloff 1999). Another 35 randomly selected households were added to each community sample to account for potential undeliverable surveys given the transient nature of these amenityoriented places. In total, the survey was sent to 4,027 households from the nine communities. A modified tailored design method (Dillman and others 2009) was used to administer the survey. Advertisements about the survey were placed in local newspapers to increase survey awareness prior to the mailing. The process included a first survey mailing, a thank you/reminder postcard, a second survey mailing, and a final survey mailing accompanied with reminder phone calls to nonrespondents. All unreturned surveys were considered non-responses following these efforts over ten weeks. To randomize sampling within households, respondents with the most recent birthday were asked to complete the survey.

To assess perceptions of beetle impacts, respondents were asked to indicate how much of the forest around their community had been killed by beetles on a scale ranging from 1 (no pines are dead) to 5 (all pines are dead). Risk perception was measured by asking respondents how concerned they were about a series of forest risks for their community (possible responses ranged from " 1 " not concerned to "5" extremely concerned). A composite measure of general risk perception was created based on results from exploratory factor analysis (alpha reliability coefficient of .89) including following variables: (1) forest fire; (2) falling trees; (3) decline in wildlife habitat; (4) impact on livestock grazing; (5) increased erosion and runoff; (6) invasive plant species; (7) loss of forests as an economic resource; (8) loss of scenic/aesthetic quality; (9) loss of tourism and recreation opportunities; (10) loss of community identity tied to the forest; and (11) impact on property values (Table 2).

The survey also assessed attitudes about forest management. The level of agreement or disagreement was measured with a series of thirteen forest management related statements was measured on a scale from 1 (strongly disagree) to 5 (strongly agree). Two factors emerged from exploratory factor analysis (Table 3). The first factor indexed as a composite variable included seven statements representing faith in forest industry (alpha reliability coefficient of .794) including: (1) forests should be managed to meet as many human needs as possible; (2) forests should have the right to exist for their own sake, regardless of human concerns and uses; (3) forests should be left to grow, develop, and succumb to natural forces without being managed by humans; (4) forests that are not used for the benefit of humans are a waste of our natural resources; (5) the present rate of logging is too great to sustain our forest in the future; (6) the economic benefits from logging usually outweigh any negative consequences; and (7) forestry practices generally produce few long-term negative effects on the environment. The second attitudinal 
Table 3 Factor analysis for forest management attitudes (using principal components extraction and varimax rotation)

\begin{tabular}{|c|c|c|}
\hline \multirow[t]{2}{*}{ Variables } & \multicolumn{2}{|l|}{ Factor loadings } \\
\hline & $\begin{array}{l}\text { Faith in forest } \\
\text { industry }\end{array}$ & $\begin{array}{l}\text { Trust in forest } \\
\text { management }\end{array}$ \\
\hline Forests should be managed to meet as many human needs as possible & .603 & \\
\hline Forests should have the right to exist for their own sake, regardless of human concerns and uses & -.690 & \\
\hline Forests should be left to grow, develop, and succumb to natural forces without being managed by humans & -.654 & \\
\hline Forests that are not used for the benefit of humans are a waste of our natural resources & .673 & \\
\hline The present rate of logging is too great to sustain our forest in the future & -.715 & \\
\hline The economic benefits from logging usually outweigh any negative consequences & .718 & \\
\hline Forestry practices generally produce few long-term negative effects on the environment & .636 & \\
\hline Forests are being managed successfully for a wide range of uses and values, not just timber & & .752 \\
\hline Forest management does a good job of including environmental concerns & & .773 \\
\hline Citizens in Colorado communities have enough say in forest management & & .659 \\
\hline Forests are being managed successfully for the benefit of future generations & & .814 \\
\hline I have confidence in the US Forest Service to manage forests in Colorado & & .874 \\
\hline The US Forest Service shares my values about how Colorado forests should be managed & & .840 \\
\hline Eigenvalue & 4.077 & 2.997 \\
\hline Percent of variance explained & $31.4 \%$ & $23.1 \%$ \\
\hline Cronbach's alpha for composite index variable & .794 & .881 \\
\hline
\end{tabular}

Table 4 Factor analysis for satisfaction with forest management (using principal components extraction and varimax rotation)

\begin{tabular}{lcc}
\hline Variables & \multicolumn{2}{l}{ Factor loadings } \\
\cline { 2 - 3 } & $\begin{array}{l}\text { Local land } \\
\text { management }\end{array}$ & $\begin{array}{l}\text { Government } \\
\text { land managers }\end{array}$ \\
\hline Private individuals and landowners & .721 & \\
Local fire departments & .550 & \\
Private logging companies & .686 & \\
Developers & .717 & \\
Homeowner associations & .699 & .598 \\
City government & & .676 \\
County Government & & .883 \\
Colorado State Forest Service & & .890 \\
Bureau of Land Management & & .861 \\
US Forest Service & & 2.107 \\
Eigenvalue & 3.760 & $21.1 \%$ \\
Percent of variance explained & $37.6 \%$ & .865 \\
Cronbach's alpha for composite & .732 & \\
$\quad$ index variable & & \\
\hline
\end{tabular}

factor indexed as a composite variable represented trust in forest management (alpha reliability coefficient of .881) and included the following variables: (1) forests are being managed successfully for a wide range of uses and values, not just timber; (2) forest management does a good job of including environmental concerns; (3) citizens in Colorado communities have enough say in forest management; (4) forests are being managed successfully for the benefit of future generations; (5) I have confidence in the US Forest Service to manage forests in Colorado; and (6) the US Forest Service shares my values about how Colorado forests should be managed.

To measure local relationships with land managers, respondents indicated levels of satisfaction from 1 (very dissatisfied) to 5 (very satisfied) with ten natural resource management entities. Two factors emerged from exploratory factor analysis (Table 4). The first factor described satisfaction with local land management including private individuals and landowners, local fire departments, private logging companies, developers, and homeowner associations. The second factor describing satisfaction with government forest management entities represented satisfaction with city government, county government, the Colorado State Forest Service, the Bureau of Land Management, and the US Forest Service. Composite variables created for measuring satisfaction with local and governmental land managers had alpha reliability coefficients of .732 and .865 respectively.

Experience with emergencies was measured in the survey by asking respondents to identify whether they have personal experience with emergencies. Based on results of factor analysis revealing one factor (eigenvalue 1.921 and $48.0 \%$ of variance), a composite variable with an alpha reliability coefficient of .64 was created for experience with the following emergencies: nearby wildland fire (.731 factor loading), avalanche or landslide (.749 factor loading), flooding (.636 factor loading), and toxic contamination (e.g., gas spill, chemical exposure) (.649 factor loading). 
Respondents were also asked to indicate their attitudes about a group of four forest industry options: biomass/ biofuels power generation, large scale timber processing, small scale timber processing, and niche marketing/production of wood products (responses ranged from 1 (strongly oppose) to 5 (strongly support)). In addition, a number of sociodemographic questions were included to evaluate the representativeness of the community samples and their effect on perceptions. These variables included age, gender, years lived in the community, annual household income (in eight levels), and educational attainment. We also asked whether respondents were currently or previously employed in agriculture or forestry.

Key survey variables were explored with one-factor analysis of variance (ANOVA) and post hoc Tukey's tests to assess community and community cluster variation. Nonparametric statistics such as Spearman's rank correlation coefficients (rho) and Kendall's Coefficient of Concordance $(W)$ were used to evaluate the extent of association among tree mortality data, amenity index values, and community rankings on survey variables where appropriate. Additionally, to evaluate any effect of collinearity, we constructed a regression model to assess the effects of the biophysical and amenity community contexts and the variable described above on general risk perception. The regression analysis used multilevel linear modeling because respondents were nested within study communities in the survey data.

\section{Results}

Tree Mortality and Amenity Index

Results of the assessment of tree mortality and the amenity index for communities are shown in Fig. 2. The nine study communities experienced different degrees of MPB disturbance. Using the 15-mile radius for forest cover and tree mortality, Walden had the highest percentage of impacted forests, followed by Kremmling and Granby. By contrast, the percent of forests killed by insects was much lower in Vail, Breckenridge, Frisco, Dillon, Silverthorne, and Steamboat Springs. It is notable that the three communities with the greatest tree mortality are situated furthest from area forests. Thus, when different spatial boundaries are used, results vary.
Fig. 2 Percentage of forests damaged by insects (15-mile radius) and amenity index scores for study communities
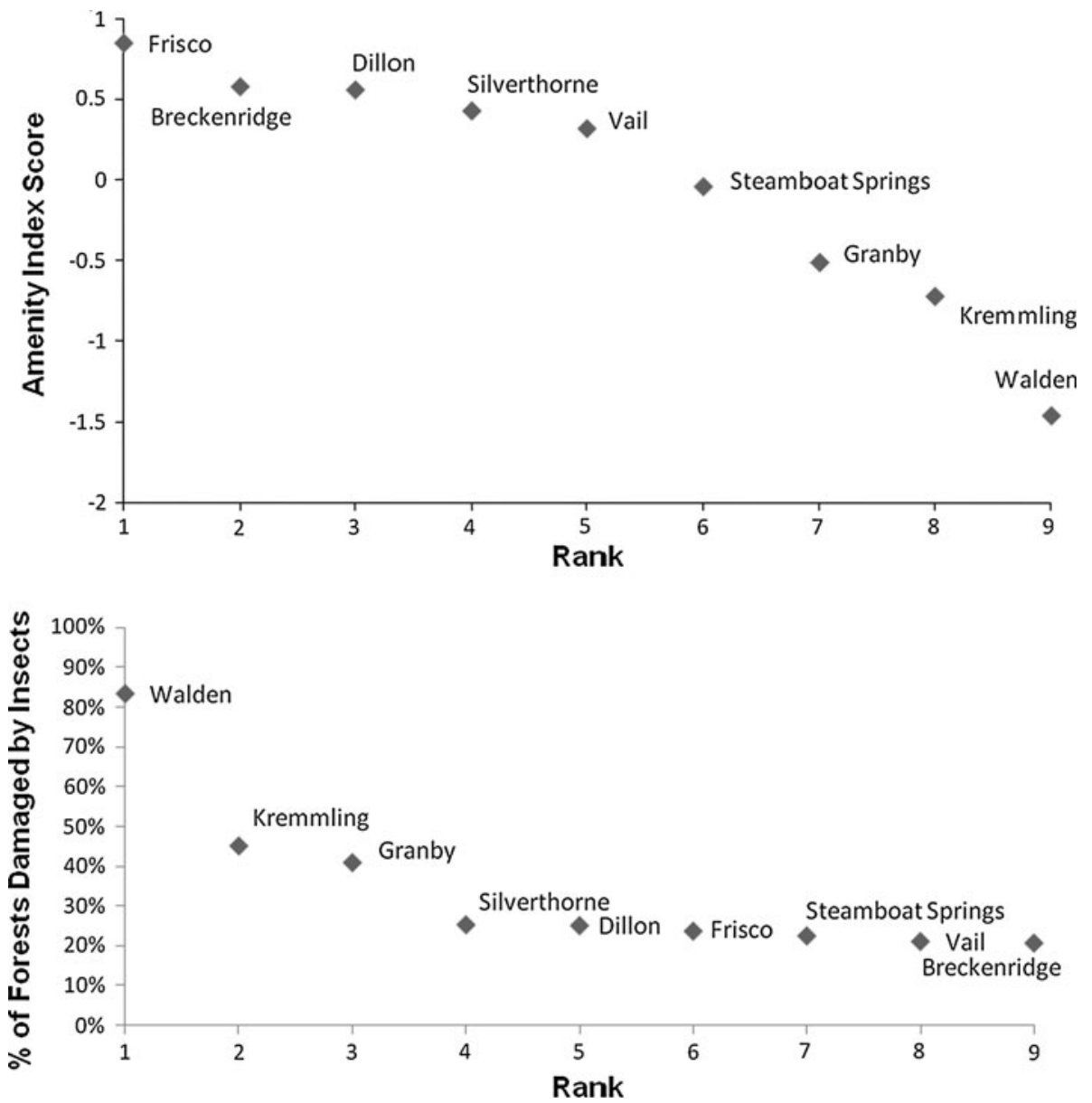
The amenity index centers on zero due to standardization and has positive or negative values. Figure 2 shows communities at different points along an amenity gradient. Frisco, Breckenridge, Dillon, Silverthorne, Vail, and Steamboat Springs form the higher-end cluster of amenity communities. Granby, Kremmling, and Walden group together at the lower end of the gradient, albeit with some heterogeneity. The results suggest there is a high negative correlation between community ranks on tree mortality and the amenity index. The nonparametric analysis confirmed that the association was statistically significant (rho $=$ $-.700, P<.05)$. However, the correlation found is coincidental and not in any way generalizable beyond this context. The relationship found in this study context between tree mortality and amenity context does have implications for forest management as discussed later in this paper.

\section{Survey Findings}

Survey data provided measures of perceived tree mortality and local perceptions of MPB impacts, associated risks, and attitudes regarding forest management and industrial options to the MPB outbreak. The overall survey response rate was $39 \%$, accounting for 4,027 surveys sent, 1,346 surveys returned, and 569 undeliverable surveys. Community response rates varied as follows: Breckenridge 40\%, Dillon 35\%, Frisco 33\%, Granby 41\%, Kremmling $35 \%$, Silverthorne $46 \%$, Steamboat Springs 35\%, Vail $34 \%$, and Walden $50 \%$. Sociodemographic variables (age, gender, years lived in community, ethnicity, household income, and educational attainment) described survey respondent characteristics and were compared to 2000 US Census data to evaluate the effects of nonresponse bias on the survey data. These communities are highly transient and 2000 Census data may not accurately describe community characteristics for 2007. Nonetheless, the aggregate survey sample was found to be older, more female, and racially more Caucasian than the general population in the study areas. The percentages of survey respondents in higher income and education categories, those owning homes, and those living in the same community at least five years were also higher than indicated by the Census. Thus, there is potential for nonresponse bias in this study. To further assess nonresponse bias, we compared sociodemographic characteristics and attitudinal responses of those reporting in the first, second, and third mailings of the survey as suggested by Armstrong and Overton (1977). No significant differences in these variables were found among respondent groups, however, the potential for nonresponse bias remains.

Community variations in respondents' sociodemographic characteristics were significant for age, household income, education, and years in residence. Incomes for
Table 5 Perceived tree mortality versus measured tree mortality

\begin{tabular}{llllc}
\hline $\begin{array}{l}\text { Study } \\
\text { community }\end{array}$ & $\begin{array}{l}\text { Perceived } \\
\text { Tree } \\
\text { mortality } \\
(\text { mean })^{\mathrm{a}}\end{array}$ & $\begin{array}{l}\text { Measured } \\
\text { Tree } \\
\text { mortality } \\
(\%)^{\mathrm{b}}\end{array}$ & $\begin{array}{l}\text { Predicted } \\
\text { perceived tree } \\
\text { mortality }^{\mathrm{c}}\end{array}$ & Residuals $^{\mathrm{d}}$ \\
\hline Granby & 3.78 & 41.0 & 3.15 & 0.63 \\
Kremmling & 3.52 & 45.2 & 3.21 & 0.31 \\
Walden & 3.41 & 83.4 & 3.73 & -0.32 \\
Silverthorne & 3.06 & 25.4 & 2.94 & 0.12 \\
Vail & 3.06 & 21.2 & 2.88 & 0.18 \\
Frisco & 3.03 & 23.8 & 2.92 & 0.11 \\
Dillon & 2.89 & 25.2 & 2.94 & -0.05 \\
Breckenridge & 2.49 & 20.8 & 2.88 & -0.39 \\
Steamboat & 2.30 & 22.6 & 2.90 & -0.60 \\
$\quad$ Springs & & & & \\
\hline
\end{tabular}

${ }^{a}$ Based on 5-pt scale ( 1 no pines are dead to 5 all pines are dead)

b Within a 15-mile radius of each study community

c Predicted values from regression of perceived tree mortality on measured tree mortality; based on 5-pt scale ( 1 no pines are dead to 5 all pines are dead)

${ }^{\mathrm{d}}$ Residuals of regression of perceived tree mortality on measured tree mortality; calculated as the differences between observed and predicted perceived tree mortalities

respondents from Vail were highest and significantly higher than those from Granby, Kremmling, and Walden. Average education levels for respondents from Granby, Kremmling, and Walden were also lower and differed significantly from those among respondents from other communities and there were higher proportions of these respondents with employment history in agriculture or forestry compared to the other communities (Table 1).

Table 5 shows comparisons between survey respondents' perceived tree mortality and the measured tree mortality for the study communities. Overall, respondents from Granby, Kremmling, and Walden, which had greater measured tree mortality, perceived higher levels of tree mortality than those from the other six communities. The correlation between community rankings on these two variables was statistically significant at the .05 level $($ rho $=.753)$. Comparing perceived tree mortality to measured tree mortality using regression (predicted values and residuals shown in Table 5), survey respondents from communities with lower technically measured tree mortalities tended to underestimate or only slightly overestimate the degree of damage by insects, while those from Granby and Kremmling overestimated the degree of forest loss. The exception to this pattern is Walden, which had the highest percentage of infested forests $(83 \%$ in a 15 -mile radius), but underestimated tree mortality. This is likely due to the fact that Walden is situated quite far from the surrounding forested areas and the percentage of tree mortality increases further from town. 
Table 6 Risk perceptions from study communities

\begin{tabular}{|c|c|c|c|c|c|c|c|c|c|c|}
\hline \multirow[t]{3}{*}{ Risk perceptions } & \multicolumn{6}{|c|}{ Lower tree mortality-higher amenity communities } & \multicolumn{3}{|c|}{$\begin{array}{l}\text { Higher tree mortality-lower } \\
\text { amenity communities }\end{array}$} & \multirow[t]{3}{*}{$\begin{array}{l}\text { ANOVA } \\
F \text {-scores }\end{array}$} \\
\hline & Frisco & Breckenridge & Dillon & Silverthorne & Vail & $\begin{array}{l}\text { Steamboat } \\
\text { Springs }\end{array}$ & Granby & Kremmling & Walden & \\
\hline & \multicolumn{6}{|c|}{ Mean values } & \multicolumn{3}{|c|}{ Mean values } & \\
\hline Forest fire $^{\mathrm{a}, \mathrm{b}}$ & $4.3^{\mathrm{GW}}$ & $4.3^{\mathrm{W}}$ & 4.5 & 4.4 & 4.5 & $4.2^{\mathrm{GKW}}$ & $4.6^{\mathrm{FS} 2}$ & $4.5^{\mathrm{S} 2}$ & $4.6^{\mathrm{BFS} 2}$ & $4.58 * * *$ \\
\hline Falling trees ${ }^{\mathrm{a}, \mathrm{b}}$ & $3.6^{\mathrm{W}}$ & $3.5^{\mathrm{W}}$ & 3.7 & $3.5^{\mathrm{W}}$ & 3.6 & $3.5^{\mathrm{W}}$ & 3.7 & 3.8 & $4.0^{\mathrm{BFS} 1 \mathrm{~S} 2}$ & $4.16 * * *$ \\
\hline $\begin{array}{l}\text { Decline in wildlife } \\
\text { habitat }\end{array}$ & 3.7 & 3.6 & $3.9^{\mathrm{S} 1}$ & $3.5^{\mathrm{DW}}$ & 3.8 & 3.6 & 3.8 & 3.7 & $3.9^{\mathrm{S} 1}$ & $2.52 *$ \\
\hline $\begin{array}{l}\text { Impact on livestock } \\
\text { grazing }\end{array}$ & $2.3^{\mathrm{KW}}$ & $2.4^{\mathrm{KW}}$ & $2.4^{\mathrm{KW}}$ & $2.4^{\mathrm{KW}}$ & $2.3^{\mathrm{GKW}}$ & $2.7^{\mathrm{W}}$ & $2.8^{\mathrm{VW}}$ & $3.0^{\mathrm{BDFS} 1 \mathrm{VW}}$ & $3.5^{\mathrm{c}}$ & $18.16^{* * * *}$ \\
\hline $\begin{array}{l}\text { Increased erosion and } \\
\text { runoff }\end{array}$ & 3.8 & $3.6^{\mathrm{DW}}$ & $4.0^{\mathrm{B}}$ & 3.7 & 3.9 & 3.8 & 3.8 & 3.8 & $4.0^{\mathrm{B}}$ & $2.64 * *$ \\
\hline Invasive plant species & 3.6 & 3.6 & 3.9 & 3.8 & 3.7 & 3.7 & 3.6 & 3.8 & 3.9 & 1.92 \\
\hline $\begin{array}{l}\text { Loss of forests as an } \\
\text { economic } \\
\text { resource }^{\mathrm{a}(\mathrm{b})}\end{array}$ & $3.3^{\mathrm{KW}}$ & $3.3^{\mathrm{KW}}$ & $3.6^{\mathrm{W}}$ & $3.4^{\mathrm{W}}$ & $3.3^{\mathrm{KW}}$ & $3.3^{\mathrm{KW}}$ & $3.7^{\mathrm{W}}$ & $3.8^{\mathrm{BFS} 1 \mathrm{VW}}$ & $4.3^{\mathrm{c}}$ & $14.83 * * *$ \\
\hline $\begin{array}{l}\text { Loss of scenic/ } \\
\text { aesthetic quality }\end{array}$ & 4.3 & 4.2 & 4.4 & 4.3 & 4.2 & 4.1 & 4.1 & 4.0 & 4.3 & 1.74 \\
\hline $\begin{array}{l}\text { Loss of tourism/ } \\
\text { recreation }\end{array}$ & 3.6 & $3.6^{\mathrm{S} 2}$ & $3.7^{\mathrm{S} 2}$ & $3.5^{\mathrm{W}}$ & $3.7^{\mathrm{S} 2}$ & $3.1^{\mathrm{BDVW}}$ & $3.5^{\mathrm{W}}$ & $3.3^{\mathrm{W}}$ & $3.9^{\mathrm{GKS} 1 \mathrm{~S} 2}$ & $5.94 * * *$ \\
\hline $\begin{array}{l}\text { Loss of community } \\
\text { identity }\end{array}$ & 3.5 & 3.6 & $3.7^{\mathrm{S} 2}$ & $3.6^{\mathrm{S} 2}$ & $3.7^{\mathrm{KS} 2}$ & $3.1^{\mathrm{DS} 1 \mathrm{VW}}$ & $3.4^{\mathrm{W}}$ & $3.2^{\mathrm{VW}}$ & $3.9^{\mathrm{GKS} 2}$ & $5.83 * * *$ \\
\hline $\begin{array}{l}\text { Impact on property } \\
\text { values }^{\mathrm{a}}\end{array}$ & $3.5^{\mathrm{W}}$ & $3.6^{\mathrm{S} 2}$ & $3.9^{\mathrm{S} 2}$ & $3.6^{\mathrm{S} 2}$ & 3.6 & $3.1^{\text {BDGKS1W }}$ & $3.8^{\mathrm{S} 2}$ & $3.7^{\mathrm{S} 2}$ & $4.0^{\mathrm{FS} 2}$ & $6.69 * * *$ \\
\hline
\end{tabular}

Means based on 5-pt scale ( 1 not concerned to 5 extremely concerned). Any superscript codes identified indicates a significant difference between the two communities using post hoc Tukey's test. Codes for communities: $B$ Breckenridge, $D$ Dillon, $F$ Frisco, S1 Silverthorne, $S 2$ Steamboat Springs, $V$ Vail, $G$ Granby, $K$ Kremmling, $W$ Walden

${ }^{a}$ Spearman correlation with the biophysical vulnerability indicator is significant at the .05 level ( ${ }^{(a)}$ marginally significant at the .1 level)

b Spearman correlation with the amenity index is significant at the .05 level ( ${ }^{(b)}$ marginally significant at the .1 level)

c Significantly different from all other communities

${ }^{\mathrm{d}}$ F-scores obtained using a one-factor ANOVA

$* P<.05$

$* * P<.01$

$* * * P<.001$

Mean values for the risk perception variables for each community are found in Table 6. Survey results showed concerns about forest related risks differed across study communities to a great extent. Significant community variations were found in concerns over all risks except for "invasive plant species" and "loss of scenic/aesthetic quality". Concerns about the two immediate threats to human safety and property (forest fire and falling trees) and the direct threats to forest-based economic interests (impact on livestock grazing, lost of forests as an economic resource, and impact on property values) were higher among respondents from the higher tree mortality and lower amenity communities. This finding was confirmed with the nonparametric Spearman correlations between these variables as shown in Table 6. It should be noted, however, that though fire risk perceptions were significantly different between the two clusters, all mean values were above four on a five-point scale. Results from post hoc Tukey's tests shown in Table 6 revealed significant differences in general (though not uniformly) between communities from different tree mortality and amenity community clusters. Further analysis using independent t-tests revealed differences between respondents from the two community groups for these risk perceptions were statistically significant at the .001 level. Concerns about broader threats to community and ecological well-being (such as decline in wildlife habitat and loss of community identity) also varied distinctly across study communities, but not corresponding to biophysical and amenity community patterns. Nonparametric analysis using Kendall's Coefficient of Concordance $(W)$ was used to assess the extent of association among community rankings for tree mortality, the amenity index, and risk perceptions. With all thirteen variables included in the analysis, Kendall's $W$ was .866 and highly significant 
Table 7 A multilevel regression model of risk perception for the aggregate survey data

\begin{tabular}{lc}
\hline Variables & $\begin{array}{c}\text { Estimates of } \\
\text { fixed effects }\end{array}$ \\
\hline Community biophysical indicator & $.913^{*}$ \\
Community amenity index & $.237^{*}$ \\
Age & .002 \\
Gender & $.283^{* * *}$ \\
Years lived in community & .000 \\
Household income & .015 \\
Educational attainment & -.030 \\
Perceived tree mortality & $.111^{* * *}$ \\
Satisfaction with local land managers & -.016 \\
Satisfaction with government land managers & $-.061^{(*)}$ \\
Faith in forest industry & $.097^{* *}$ \\
Trust in forest management & $-.106^{* *}$ \\
Personal experience with emergencies & .031 \\
\hline
\end{tabular}

(*) $P<.10$

$* P<.05$

$* * P<.01$

$* * * P<.001$

$\left(X^{2}=93.57, \mathrm{df}=12, P<.001\right)$, meaning there was strong agreement overall in variable ranking across communities.

To further validate the relationship found between biophysical and amenity contexts of forest disturbance and local risk perception in the community-level analysis above, we evaluated a multilevel regression model of general risk perception using the two contextual variables and other variables from the aggregate survey following a conceptual model of factors influencing risk perception (including variables for perceived tree mortality, satisfaction with local land managers, satisfaction with government land managers, faith in forest industry, trust in forest management, personal experience with emergencies and demographic control variables) (Table 7). Because random effect estimates for the coefficients of independent variables were not significantly different from zero, only the intercept was estimated as a random effect while the effects of all the independent variables were set as fixed in the model. Both tree mortality and the amenity index were positively and significantly related to risk perception $(P<.05)$. The tree mortality indicator had a larger effect than the amenity index variable (respective estimates of fixed effects: 0.913 vs. 0.237). This means that one unit increase in tree mortality is associated with a larger increase in general risk perception than one unit increase in the community amenity index. Therefore, all other factors being equal, respondents from the higher tree mortality-lower amenity community cluster tend to have a greater level of risk perception than those from the lower tree mortality-higher amenity community group. This finding is generally consistent with results of the analysis on risk perception variables at the community level discussed above. In addition to the two community contextual variables, gender, perceived tree mortality, faith in forest industry, and trust in forest management were also significant in their relationships with risk perception.

Analysis using a one-way ANOVA followed by post hoc Tukey's tests showed local perspectives on forest industry and forest management also differed largely by community clusters (see Table 8). Overall, respondents from Granby, Kremmling, and Walden showed more enthusiastic attitudes toward human utilization of forest resources and less trust in current forest management than those from the lower tree mortality-higher amenity communities. General opinions on forest values and management were closely related to views on specific forest industries. The higher tree mortality-lower amenity communities voiced significantly greater support for all forest industry options, especially those related to logging and timber processing. As noted in Table 7, examination of Spearman rank-order correlations revealed at least one of the two community contextual measures was significantly or almost significantly related to each of the six industry/management variables. With the tree mortality indicator, the amenity index, and the six forest industry/management related variables included in the nonparametric rank analysis, Kendall's $W$ was $.908\left(X^{2}=57.19, \mathrm{df}=7, P<.001\right)$ indicating a high degree of association among rankings across communities.

Table 9 summarizes levels of satisfaction with various land management entities, revealing significant variations across communities. Although differences found between communities regarding these variables did not exactly mirror the community clusters, respondents from the three higher tree mortality-lower amenity communities in general indicated higher satisfaction level with local land mangers (particularly private logging companies) and lower satisfaction with government land managers (particularly city government and the US Forest Service). Tree mortality was significantly or marginally significantly correlated with satisfaction with private landowners, private logging companies, developers, and the Bureau of Land Management, while the amenity index was strongly correlated with satisfaction levels with private logging companies, city government, and county government. The degree of correspondence of community rankings on the tree mortality and amenity indicators and the ten satisfaction variables was lower (Kendall's $W=.773$ ) as compared to those of the previous two sets of ranks, but still attained statistical significance at the .001 level $\left(X^{2}=76.53, \mathrm{df}=11\right)$. 
Table 8 Community attitudes regarding forest management and industry

\begin{tabular}{|c|c|c|c|c|c|c|c|c|c|c|}
\hline \multirow[t]{3}{*}{ Attitudes } & \multicolumn{6}{|c|}{ Lower tree mortality-higher amenity communities } & \multicolumn{3}{|c|}{$\begin{array}{l}\text { Higher tree mortality-lower } \\
\text { amenity communities }\end{array}$} & \multirow[t]{3}{*}{$\begin{array}{l}\text { ANOVA } \\
F \text {-scores }\end{array}$} \\
\hline & Frisco & Breckenridge & Dillon & Silverthorne & Vail & $\begin{array}{l}\text { Steamboat } \\
\text { Springs }\end{array}$ & Granby & Kremmling & Walden & \\
\hline & \multicolumn{6}{|c|}{ Mean values } & \multicolumn{3}{|c|}{ Mean values } & \\
\hline $\begin{array}{l}\text { Faith in Forest } \\
\text { Industry }\end{array}$ & $2.5^{\mathrm{GKW}}$ & $2.5^{\mathrm{GKW}}$ & $2.5^{\mathrm{GKW}}$ & $2.6^{\mathrm{GKW}}$ & $2.5^{\mathrm{GKW}}$ & $2.5^{\mathrm{GKW}}$ & $2.9^{\mathrm{c} \mathrm{W}}$ & $3.1^{\mathrm{c} \mathrm{W}}$ & $3.6^{\mathrm{c} \mathrm{GK}}$ & $49.66 * * *$ \\
\hline $\begin{array}{l}\text { Trust in Forest } \\
\text { Management }^{\mathrm{a}}\end{array}$ & $2.9^{\mathrm{DGKW}}$ & $2.7^{\mathrm{KW}}$ & $2.5^{\mathrm{FS} 2 \mathrm{VW}}$ & $2.7^{\mathrm{KW}}$ & $2.8^{\mathrm{DGKW}}$ & $3.0^{\mathrm{DGKW}}$ & $2.5^{\mathrm{FS} 2 \mathrm{VW}}$ & $2.3^{\mathrm{BFS} 1 \mathrm{~S} 2 \mathrm{~V}}$ & $2.0^{\mathrm{c} \mathrm{G}}$ & $21.34 * * *$ \\
\hline \multicolumn{11}{|c|}{ Forest industry options } \\
\hline $\begin{array}{l}\text { Biomass/ } \\
\text { Biofuels Power } \\
\text { Generation }^{\text {(a)(b) }}\end{array}$ & $3.7^{\mathrm{GW}}$ & $3.6^{\mathrm{W}}$ & $3.6^{\mathrm{W}}$ & $3.5^{\mathrm{W}}$ & $3.5^{\mathrm{W}}$ & $3.5^{\mathrm{W}}$ & $3.8^{\mathrm{FW}}$ & $3.6^{\mathrm{W}}$ & $4.3^{\mathrm{c} G K}$ & $10.99 * * *$ \\
\hline $\begin{array}{l}\text { Large scale } \\
\text { timber } \\
\text { processing } \\
\end{array}$ & $2.2^{\mathrm{GKW}}$ & $2.3^{\mathrm{GKW}}$ & $2.4^{\mathrm{GKW}}$ & $2.4^{\mathrm{GKW}}$ & $2.1^{\mathrm{GKW}}$ & $2.2^{\mathrm{GKW}}$ & $3.4^{\mathrm{c} \mathrm{W}}$ & $3.3^{\mathrm{c} \mathrm{W}}$ & $4.0^{\mathrm{c} G K}$ & $51.92 * * *$ \\
\hline $\begin{array}{l}\text { Small scale } \\
\text { timber } \\
\text { processing }^{\mathrm{a}(\mathrm{b})}\end{array}$ & $3.3^{\mathrm{GKW}}$ & $3.4^{\mathrm{GKW}}$ & $3.4^{\mathrm{GKW}}$ & $3.4^{\mathrm{GKW}}$ & $3.1^{\mathrm{GKW}}$ & $3.3^{\mathrm{GKW}}$ & $4.0^{\mathrm{c} \mathrm{W}}$ & $4.2^{\mathrm{c}}$ & $4.4^{\mathrm{c} \mathrm{G}}$ & $31.86 * * *$ \\
\hline $\begin{array}{l}\text { Niche } \\
\text { marketing }\end{array}$ & $3.7^{\mathrm{W}}$ & $3.7^{\mathrm{KW}}$ & $3.7^{\mathrm{W}}$ & $3.7^{\mathrm{KW}}$ & $3.4^{\mathrm{GKW}}$ & $3.5^{\mathrm{GKW}}$ & $4.0^{\mathrm{S} 2 \mathrm{~V}}$ & $4.1^{\mathrm{BS} 1 \mathrm{~S} 2 \mathrm{~V}}$ & $4.3^{c}$ & $12.31 * * *$ \\
\hline
\end{tabular}

Means based on 5-pt scale ( 1 strongly disagree to 5 strongly agree or 1 strongly oppose to 5 strongly support). Any superscript codes identified indicates a significant difference between the two communities using post hoc Tukey's test. Codes for communities: $B$ Breckenridge, $D$ Dillon, $F$ Frisco, $S 1$ Silverthorne, $S 2$ Steamboat Springs, $V$ Vail, $G$ Granby, $K$ Kremmling, $W$ Walden

${ }^{a}$ Spearman correlation with the biophysical vulnerability indicator is significant at the .05 level ( ${ }^{(a)}$ marginally significant at the .1 level)

${ }^{\mathrm{b}}$ Spearman correlation with the amenity index is significant at the .05 level ( ${ }^{(\mathrm{b})}$ marginally significant at the .1 level)

c Significantly different from all communities in the lower tree mortality-higher amenity community cluster: Breckenridge, Dillon, Frisco, Silverthorne, Steamboat Springs, and Vail

${ }^{\mathrm{d}}$ F-scores obtained using a one-factor ANOVA

$* P<.05$

$* * P<.01$

$* * * P<.001$

\section{Discussion}

The five county study area in north central Colorado may seem relatively homogenous when viewed from a macro lens. This is alpine country with amenity-oriented communities experiencing a common forest disturbance by mountain pine beetles. Yet further exploration reveals considerable heterogeneity across this landscape. Variations in tree mortality, forest proximity, amenity characteristics, and perceptions and attitudes of community residents regarding the MPB outbreak experience reveal contextual factors with important forest management implications. Survey data highlighted the keen saliency of the loss of trees for local residents across this landscape. This experience, while certainly felt at the individual level, appears to be conditioned and shared in different ways at the community level. This is a key finding for managing forest disturbances.

The relationship found between tree mortality and amenity characteristics across the communities is merely contextual. Higher elevation communities located further from the epicenter of beetle activity to the north in Routt and Grand Counties have greater species diversity in their forests making the landscape somewhat less vulnerable to MPB activity. Their dominant recreation and amenity orientation is also tied to their mountain setting. Communities situated farther from forests may not have tree mortality issues in close proximity to homes, city structures, and daily activity, but residents were cognizant of and concerned about forest disturbance in their greater area and in their views of distant mountainsides. Being cognizant of the forest composition as well as community characteristics is important for forest management. It would be tempting to assume that communities situated closer to areas with greater tree mortality from MPB would have heightened sensitivities, risk perceptions, and demands for aggressive forest management. Despite the strong correlation between perceived and measured tree mortality in general across communities, some variability was found between predicted and observed values in perceived tree mortality. 


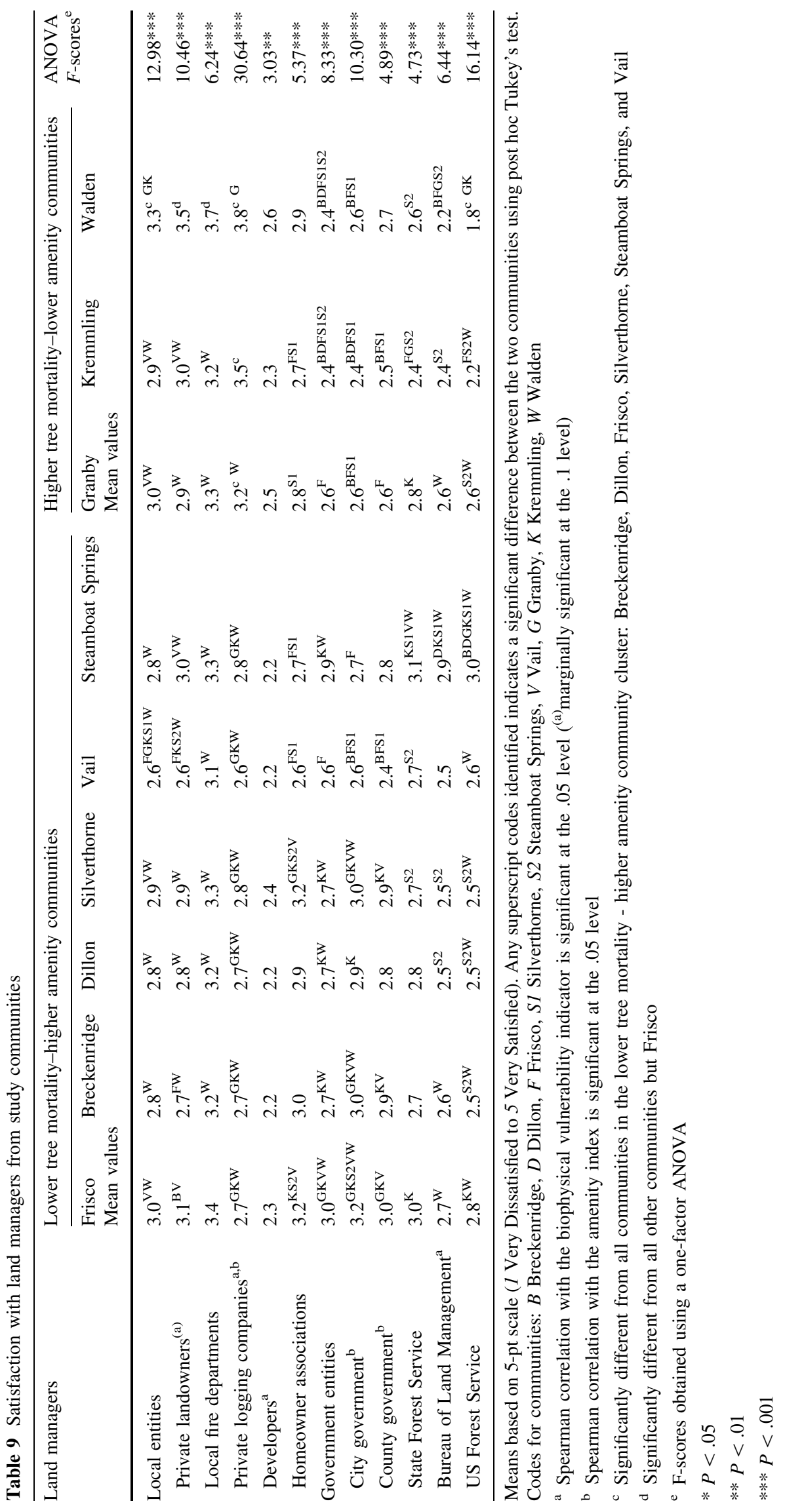


These findings suggest value in regular communication between communities and forest managers about the physical extent of MPB impacts as they evolve over time to coordinate treatment efforts.

Community factors beyond proximity to beetle infested forests are influential in framing local responses. Simple ANOVA and nonparametric analyses show correspondence between tree mortality and amenity index values and perceived MPB impacts, risk perceptions, and forest management attitudes. Both the biophysical indicator and the amenity index were positive and significant in their relationships with risk perception in the multivariate analysis. In a relevant research on human response to forest disturbance in the same study area, we also found the independently significant effects of the two community contextual variables (Qin and Flint 2010). The results of the multilevel regression model of risk perception largely confirm those at the community level, and thus provide further support for the linkages between local perceptions and the biophysical/ amenity context. Incorporating human dimensions of forest disturbances adds explanatory and interpretive power to assessments of heterogeneity across changing landscapes beyond what can be learned from biophysical indicators alone. The amenity index and the assessment of tree mortality around communities were incorporated to better understand the biophysical and socioeconomic context to which we could add perceptual data. While field work made clear MPB activity was more extensive in Grand and Jackson counties and the communities in these counties were quite different from the destination resort communities such as Vail and Breckenridge, no causal relationship was expected in bringing these indicators together in the analysis. As the disturbance by MPBs has expanded range since the time of this study, it is also possible that new contextual combinations of tree mortality and amenity level have emerged. Longitudinal study of these parameters and full examination of the aggregate socioeconomic and ecological community contexts would be helpful in the future.

Employment history and characteristics may play a key role in conditioning the responses by community residents. Granby, Kremmling and Walden were found to have more recent employment in the agriculture and forestry sectors compared to their lower tree mortality - higher amenity counterparts. This community orientation likely explains attitudes related to greater faith in forest industry, less trust in forest management by government entities, and greater support for industrial forestry options to managing dead and dying timber stands. Resentment was common among long-standing residents in these communities about the decline in timber industry activity and related jobs and they readily made connections between the lack of logging and the spread of bark beetles. A Kremmling resident highlighted this sentiment:
"Our roots are in logging and our roots are in timbering so we feel that the government has ignored this [bark beetle] issue to the point where it's gotten to an epidemic and now uncontrollable."

Residents from higher amenity communities, with higher recreation oriented employment and second home development, were still highly concerned about forest risks, but more satisfied with the way forests were being managed, despite the beetles. As found in the survey analysis, respondents from both community clusters were equally concerned about changing scenic qualities of their forests. However, those from lower tree mortality - higher amenity communities were more satisfied with forest management and less inclined to accept industrial or aggressive timber harvesting solutions to managing the MPB outbreak which were seen to be at odds with their aesthetic and recreational forest use.

These results are consistent with Parkins and MacKendrick (2007) in as much as both studies found discrepancies in perceptions and vulnerability across communities experiencing similar forest disturbances. However, in north central Colorado, the amenity context suggests residents from all communities have some element of economic risk associated with the loss of trees to MPBs despite the relatively small scale of forestry and other extractive resource activities found mostly in the lower amenity communities. In Parkins and MacKendrick's British Columbia communities, economic risk was seen as tied predominantly to timber dependence where they found little variation in satisfaction and trust in forest management. In Colorado, measures of trust in forest management, faith in forest industry, and satisfaction with forest management varied in ways corresponding to levels of tree mortality and amenity orientation. This suggests that regional responses to forest insect disturbances may differ depending on the type of forest-based economic orientation. Industrial timber management options should be carefully located to avoid conflicts and to tap into labor pools and communities with historical ties to extractive industry as well as high employment needs to ameliorate socioeconomic vulnerabilities.

Forest management strategies planned at a landscape or regional scale can prioritize strategies to fit varying community orientations. A one-size-fits-all approach is likely to clash with local orientations and may present obstacles to management implementation (Brunson and Shindler 2004). While communities may experience the same physical process of forest disturbance by insects, managers can reduce conflict by listening carefully to the perspectives from local communities before designing and communicating mitigation strategies. Ameliorating distrust and resentment may need to come first in building relationships between communities and forest managers. Frustratingly, time needed for 
these efforts may not fit well with needs for expedited mitigation of rapidly developing risks, such as fire. However, by taking time to coordinate mitigation strategies to fit the variety of community contexts, it may be that a mosaic of management strategies on the landscape may fit the heterogeneity of perspectives, reduce conflicts, and engender local support and involvement in mitigating risks related to forest disturbance. More aggressive timber thinning and clearing may be acceptable in communities with a logging legacy, while similar efforts may need to be communicated in terms of facilitating forest rejuvenation and handled with more care for aesthetic conditions in higher amenity communities.

While every community is different in terms of biophysical, sociocultural, and economic characteristics, identifying meaningful community clusters based on tree mortality, amenity index, and/or other data can serve as a starting point for linking diverse human and natural influences in the ecological management of forest disturbances. This is in no way meant to discount the importance of heterogeneity within communities experiencing forest disturbance. Amenity communities are highly transient and likely to reflect new and changing demographics and attitudinal orientations as newcomers mix with longtime residents. This paper instead shows that macro patterns across landscapes can be discernable by blending research methodologies. Data availability at the community level can be problematic (Parkins and MacKendrick 2007), but indices used here can be adapted to suit different contexts and data availability. Social science research methods can help to bring perceptual data to merge with landscape-scale social and biophysical data to understand heterogeneity across disturbed ecosystems.

Respondents expressed considerable awareness of these differences and frequently compared their experiences to other communities. In discussing the region's experience with MPBs, a Walden resident offered the following observation summing up the need to recognize community differences:

"The issues are definitely different in each community. The issues in Steamboat are different than they are here. Although we have the same problem, sometimes a blanket policy is not good because the issues are different. There may be some common themes that some policy decisions can be made on, yes. But each community needs to handle it, you know, that benefits their community. Each one - because each has different values and objectives."

\section{Conclusions}

Regional landscape planning and design is important for accommodating the diversity of community contexts and varying levels of acceptance for management strategies and for increasing the saliency and legitimacy of scientific and policy approaches (Nassauer and Opdam 2008). By bringing together community representatives and interests across the landscape, regional interaction may help promote common goals while protecting the interests of particular localities and communities (Flint and others 2010). Good relationships between natural resource managers and residents across changing landscapes depend upon the ability to incorporate heterogeneity in strategies and management plans. Communication is also an essential element. Engagement-oriented social science research tools can help to facilitate local assessments, but open-dialogue and stakeholder inclusion can go a long way as well (Wondolleck and Yaffee 2000). The integration of biophysical, socioeconomic, and perceptual data undertaken in this case will hopefully open opportunities for more extensive efforts within the study area and beyond to more fully understand the value of incorporating multiple dimensions of landscape heterogeneity and their resource management implications.

Acknowledgments This research was supported by funding from the USDA Forest Service's Human and Natural Resource Interactions Program at the Pacific Northwest Research Station and Region 2. The authors greatly appreciate contributions made by Michael Daab, Jacob Hendee, Mallory Dolan, Caitlin McCoy, Coryn Shiflet, participating residents from the study communities, and anonymous reviewers. Figure 1 replicated with permission from Springer Publishing Company from Qin and Flint 2010 in Human Ecology.

\section{References}

Abbott B (2008) An economic analysis of mountain pine beetle impacts in a global context. Working Paper 2008-02, Resource Economics and Policy Analysis Research Group, University of Victoria, Victoria, British Columbia, Canada

Armstrong JS, Overton TS (1977) Estimating nonresponse bias in mail surveys. Journal of Marketing Research 14:396-402

Bartuska AM (1999) Cross boundary issues to manage for healthy forest ecosystems. In: Klopatek JM, Gardner RH (eds) Landscape ecological analysis. Springer, New York, pp 24-34

Brennan MA, Flint CF, Luloff AE (2008) Local culture and rural development: a neglected relationship. Sociologia Ruralis 49(1): 97-112

Brunson MW, Shindler BA (2004) Geographic variation in social acceptability of wild fuels management in the western United States. Society and Natural Resources 17:661-678

Chang W, Lantz VA, MacLean DA (2009) Public attitudes about forest pest outbreaks and control: case studies in two Canadian provinces. Forest Ecology and Management 257:1333-1343

Chi G, Marcouiller DW (2010) Isolating the effect of natural amenities on population change at the local level. Regional Studies (ifirst) http://dx.doi.org/10.1080/00343400903496394

Christensen NL Jr (1997) Managing for heterogeneity and complexity on dynamic landscapes. In: Pickett STA, Ostfeld RS, Shachak M, Likens GE (eds) The ecological basis of conservation: heterogeneity, ecosystems, and biodiversity. Chapman and Hall, New York, pp 167-186 
Connelly NA, Brown TL, Decker DJ (2003) Factors affecting response rates to natural resource-focused mail surveys: empirical evidence of declining rates over time. Society \& Natural Resources 16:541-549

Cronon W (1996) Uncommon ground: rethinking the human place in nature. WW Norton \& Co., New York

Dale VH, Joyce LA, McNulty S, Neilson RP, Ayres MP, Flannigan MD, Hanson PJ, Irland LC, Lugo AE, Peterson CJ, Simberloff D, Swanson FJ, Stocks BJ, Wotton M (2001) Climate change and forest disturbance. BioScience 51:723-734

Davidson RA, Shah HC (1997) An urban earthquake disaster risk index. Stanford University: The John A. Blume Earthquake Engineering Center, Department of Civil and Environmental Engineering

Dillman DA, Smyth JD, Christian LM (2009) Internet, mail, and mixed mode surveys: the tailored design method. Wiley, Hoboken

Flint CG (2006) Community perspectives on spruce beetle impacts on the Kenai Peninsula, Alaska. Forest Ecology and Management 227(3):207-218

Flint CG (2007) Changing forest disturbance regimes and risk perceptions in Homer, Alaska. Risk Analysis 27(6):1597-1608

Flint CG, Haynes R (2006) Managing forest disturbances and community response: lessons from the Kenai Peninsula, Alaska. Journal of Forestry 104(3):269-275

Flint CG, Luloff AE (2007) Community activeness in response to forest disturbance in Alaska. Society and Natural Resources 20(5):431-450

Flint CG, McFarlane B, Müller M (2009) Human dimensions of forest disturbance by insects: an international synthesis. Environmental Management 43(6):1174-1186

Flint CG, Theodori GL, Luloff AE (2010) Extending the concept of community interaction to explore regional fields. Journal of Rural Social Science 25(1):22-36

Forman RTT (1999) Horizontal processes, roads, suburbs, societal objectives and landscape ecology. In: Klopatek JM, Gardner RH (eds) Landscape ecological analysis. Springer, New York, pp 35-53

Fry GLA (2001) Multifunctional landscapes-towards transdisciplinary research. Landscape and Urban Planning 57:159-168

Ganning J, Flint CF (2010) Constructing a community level amenity index. Society and Natural Resources 23(12):1253-1258

Guadagnoli E, Velicer WF (1988) Relation of sample size to the stability of component patterns. Psychological Bulletin 103(2): 265-275

Haber W (2004) Landscape ecology as a bridge from ecosystems to human ecology. Ecological Research 19:99-106

Hackett J (2007) Colorado's mountain pine beetle infestation offers important lessons about managing future forests. Colorado Conservator 23(2):8-9

Leatherman DA (2008) 2008 Report on the Health of Colorado's Forest. Accessed online February 11, 2010: http://csfs.colostate. edu/pdfs/894651_08FrstHlth_www.pdf

Luloff AE (1999) The doing of rural community development research. Rural Society 9(1):313-327

MacCallum RC, Widaman KF, Preacher KJ, Hong S (2001) Sample size in factor analysis: the role of model error. Multivariate Behavioral Research 36(4):611-637

McConnell T (1995) Aerial surveys: Quality, credibility, value - is it possible? In Proceedings of the Aerial Pest Detection and Monitoring Workshop. USDA Forest Service, Northern Region Forest Pest Management Report 95-4, pp 82-87

McFarlane BL, Wilson DOT (2008) Perceptions of ecological risk associated with mountain pine beetle (Dendroctonus ponderosae) infestations in Banff and Kootenay National Parks of Canada. Risk Analysis 28:203-212
McFarlane BL, Stumpf-Allen RCG, Watson DO (2006) Public perceptions of natural disturbance in Canada's national parks: the case of the mountain pine beetle (Dendroctonus ponderosae Hopkins). Biological Conservation 130:340-348

McGranahan DA (1999) Natural amenities drive rural population change. US Department of Agriculture. Agricultural Economic Report No. 781. Food and Rural Economics Division, Economic Research Service: Washington, DC

Molnar JJ, Schelhas J, Holeski C (2007) Nonindustrial private forest landowners and the southern pine beetle: factors affecting monitoring, preventing, and controlling infestations. Southern Journal of Applied Forestry 31(2):93-98

Müller M, Job H (2009) Managing natural disturbances in protected areas: tourists' attitude toward the bark beetle in a German national park. Biological Conservation 142:375-383

Nassauer JI (1995) Culture and changing landscape structure. Landscape Ecology 10(4):229-237

Nassauer JI (2005) Using cultural knowledge to make new landscape patterns. In: Wiens JA, Moss MR (eds) Issues in landscape ecology. Cambridge University Press, Cambridge, pp 274-280

Nassauer JI, Opdam P (2008) Design in science: extending the landscape ecology paradigm. Landscape Ecology 23:633-644

Nelson H (2007) Does a crisis matter? Forest policy responses to the mountain pine beetle epidemic in British Columbia. Canadian Journal of Agricultural Economics 55:459-470

Oliver CD, Larson BC (1996) Forest stand dynamics. Wiley, New York

Ostfeld RS, Pickett STA, Shachak M, Likens GE (1997) Defining the scientific issues. In: Pickett STA, Ostfeld RS, Shachak M, Likens GE (eds) The ecological basis of conservation: heterogeneity, ecosystems, and biodiversity. Chapman and Hall, New York, pp 3-15

Parkins JR, MacKendrick NA (2007) Assessing community vulnerability: a study of the mountain pine beetle outbreak in British Columbia, Canada. Global Environmental Change 17:460 471

Patriquin MN, Wellstead AM, White WA (2007) Beetles, trees, and people: regional economic impact sensitivity and policy considerations related to the mountain pine beetle infestation in British Columbia, Canada. Forest Policy and Economics 9:938-946

Pickett STA, Cadenasso ML (1995) Landscape ecology: spatial heterogeneity in ecological systems. Science 269:331-334

Pickett STA, White PS (eds) (1985) The ecology of natural disturbance and patch dynamics. Academic Press, San Diego

Pickett STA, Burch WR, Dalton SE, Foresman TW, Grove JM, Rowntree R (1997) A conceptual framework for the study of human ecosystems in urban areas. Urban Ecosystems 1(4):185199

Qin H, Flint CG (2010) Capturing community context of human response to forest disturbance by insects: a multi-method assessment. Human Ecology 38(4):567-579

Radeloff VC, Hammer RB, Voss PR, Hagen AE, Field DR, Mladenoff DL (2001) Human demographic trends and landscape level forest management in the northwest Wisconsin pine barrens. Forest Science 47(2):229-241

Riebsame WE, Robb JJ, Gosnell H, Theobald D (1997) Atlas of the new west. WW Norton \& Co., New York

Tress B, Tress G (2001) Capitalising on multiplicity: a transdisciplinary systems approach to landscape research. Landscape and Urban Planning 57:143-157

Turner M (1989) Landscape ecology: the effect of pattern on process. Annual Review of Ecology and Systematics 20:171-197

Turner M (2005) Landscape ecology in North America: past, present and future. Ecology 86:1967-1974

US Bureau of the Census (2000) Census 2000 Summary Files 1 and 3. US Census Bureau, Washington, DC 
Wiens JA (1995) Landscape mosaics and ecological theory. In: Hansson L, Fahrig L, Merriam G (eds) Mosaic landscapes and ecological processes. Chapman and Hall, London, pp 1-26

Wiens JA (2000) Ecological heterogeneity: an ontogeny of concepts and approaches. In: Hutchings MJ, John EA, Stewart AJA (eds) The ecological consequences of environmental heterogeneity. Blackwell Science Limited, Oxford, pp 9-31
Winkler R, Field DR, Luloff AE, Krannich RS, Williams T (2007) Social landscapes of the Inter-mountain West: a comparison of "Old West" and "New West" communities. Rural Sociology 72(3):478-501

Wondolleck J, Yaffee S (2000) Making collaboration work. Island Press, Washington 